\title{
Challenges in the diagnosis and management of acromegaly: a focus on comorbidities
}

\author{
Alin Abreu ${ }^{1}$ - Alejandro Pinzón Tovar ${ }^{2} \cdot$ Rafael Castellanos $^{3} \cdot$ Alex Valenzuela $^{4}$ • \\ Claudia Milena Gómez Giraldo ${ }^{5} \cdot$ Alejandro Castellanos Pinedo $^{6}$. \\ Doly Pantoja Guerrero ${ }^{7} \cdot$ Carlos Alfonso Builes Barrera $^{8} \cdot$ Humberto Ignacio Franco $^{9}$. \\ Antônio Ribeiro-Oliveira Jr. ${ }^{10} \cdot$ Lucio Vilar $^{11} \cdot$ Raquel S. Jallad $^{12} \cdot$ \\ Felipe Gaia Duarte ${ }^{12}$ - Mônica Gadelha ${ }^{13}$ - Cesar Luiz Boguszewski ${ }^{14}$. \\ Julio Abucham ${ }^{15}$ - Luciana A. Naves ${ }^{16}$ - Nina Rosa C. Musolino ${ }^{17}$. \\ Maria Estela Justamante de Faria ${ }^{18}$ - Ciliana Rossato ${ }^{18}$ Marcello D. Bronstein ${ }^{12}$
}

Published online: 8 June 2016

(C) The Author(s) 2016. This article is published with open access at Springerlink.com

\begin{abstract}
Introduction Acromegaly is a rare, insidious disease resulting from the overproduction of growth hormone $(\mathrm{GH})$ and insulin-like growth factor 1 (IGF-1), and is associated with a range of comorbidities. The extent of associated complications and mortality risk is related to length of exposure to the excess GH and IGF-1, thus early diagnosis and treatment is imperative. Unfortunately, acromegaly is
\end{abstract}

Marcello D. Bronstein

mdbronstein@uol.com.br

1 Endocrinology Unit, Centro Médico Imbanaco Cali, Cali, Colombia

2 Internal Medicine Department, Hospital of Neiva, University Surcolombiana, Neiva, Colombia

3 Internal Medicine Department, University Industrial of Santander, Bucaramanga, Colombia

4 Department of Internal Medicine, Endocrinology Fundación Cardio-Infantil, Instituto de Cardiología, Universidad del Rosario, Bogotá, Colombia

5 Endocrinology Unit, Hospital Universitario San Ignacio, Bogotá, Colombia

6 Internal Medicine Department, Hospital San Jerónimo de Montería, Montería, Córdoba, Colombia

7 Endocrinology Unit, Hospital Universitario Departamental de Nariño, CENTRO de Endocrinologia CENDOO, Universidad Nacional de Colombia, Pasto, Colombia

8 Endocrinology Department, Hospital Universitario San Vicente Fundación, Universidad de Antioquia, Medellín, Colombia

9 Endocrinology Faculty, Universidad Caldas, Manizales, Colombia

10 Federal University of Minas Gerais, Belo Horizonte, Brazil often diagnosed late, when patients already have a wide range of comorbidities. The presence of comorbid conditions contributes significantly to patient morbidity/mortality and impaired quality of life.

Methods We conducted a retrospective literature review for information relating to the diagnosis of acromegaly, and its associated comorbidities using PubMed. The main aim of this review is to highlight the issues of comorbidities in

11 Endocrinology and Chair, Division of Endocrinology, Hospital das Clínicas, Pernambuco Federal University Medical School, Recife, Brazil

12 Neuroendocrine Unit, Division of Endocrinology and Metabolism, Hospital das Clínicas, University of São Paulo Medical School, Av. Dr. Eneas de Carvalho, 255, $7^{\circ}$ andar, sala 7037, São Carlos, SP CEP 05403-000, Brazil

13 Endocrine Section, Medical School and Hospital Universitário Clementino Fraga Filho, Universidade Federal do Rio de Janeiro, Rio de Janeiro, Brazil

14 Department of Internal Medicine, Endocrine Division (SEMPR), Federal University of Paraná, Curitiba, Brazil

15 Neuroendocrine Unit, Escola Paulista de Medicina, Universidade Federal de São Paulo, São Paulo, SP, Brazil

16 Department of Endocrinology, Faculty of Medicine, University of Brasilia, Brasília, Brazil

17 Neuroendocrine Unit, Division of Neurosurgery, Hospital das Clínicas, University of Sao Paulo School of Medicine, São Paulo, SP, Brazil

18 Department of Odontology, Central Unit, Hospital das Clínicas, University of Sao Paulo School of Medicine, São Paulo, SP, Brazil 
acromegaly, and to reinforce the importance of early diagnosis and treatment.

Findings and conclusions Successful management of acromegaly goes beyond treating the disease itself, since many patients are diagnosed late in disease evolution, they present with a range of comorbid conditions, such as cardiovascular disease, diabetes, hypertension, and sleep apnea. It is important that patients are screened carefully at diagnosis (and thereafter), for common associated complications, and that biochemical control does not become the only treatment goal. Mortality and morbidities in acromegaly can be reduced successfully if patients are treated using a multimodal approach with comprehensive comorbidity management.

Keywords Acromegaly diagnosis - Acromegaly comorbidities · Latin America

\section{Introduction}

Acromegaly is a rare, insidious disease commonly caused by a pituitary adenoma, which overproduces growth hormone $(\mathrm{GH})$, and results in increased levels of insulin-like growth factor 1 (IGF-1) [1-3]. Some studies estimate that it affects 86-240 per million of the population [4], though others have estimated its prevalence at $40-70$ per million $[5,6]$. Despite being a rare disease, its related comorbidities and the life-long management required mean that acromegaly can be a large burden [5]. Unfortunately, the delay between the initial appearance of symptoms and diagnosis can be very long, often in the range of 7-10 years [7-9]. If left untreated, the prolonged exposure to GH and IGF-1 is associated with worsening of comorbidities [7, 10, $11]$, and poorer quality of life $[9,12]$ and increased mortality risk $[7,10,11]$. Furthermore, a delay in diagnosis has been associated with psychosocial impairment, including depression, body image distortion, and social withdrawal $[13,14]$. As such, early diagnosis and treatment is extremely important to allow for earlier initiation of appropriate treatment, which in turn would lead to more successful disease management and ultimately better outcomes.

\section{Diagnosis}

There have been several key advances over the last two decades in this disease, including the development of assays with increased sensitivity for GH and IGF-1 [15, 16], widespread use of magnetic resonance imaging (MRI) for pituitary examination [17], automated software to evaluate the physical changes associated with the disease [18], and several novel therapeutic approaches [19]. Despite this, the diagnosis of these patients does not seem to have changed in over 25 years, nor have the signs and symptoms associated with the disease [9]. Most patients still have marked manifestations of acromegaly at diagnosis, suggesting that acromegaly remains clinically underrecognized.

Although acromegaly manifests with distinct physical characteristics, diagnosis of the disease in its early stages can be difficult due to its insidious nature, meaning that neither the patient, their families nor their physicians may notice these changes. The recognition that acromegaly can be accompanied by apparently normal GH concentrations and dynamics, mild or absent clinical features and pituitary tumors that are too small to be detected by MRI, must contribute to this difficulty, and indicates the importance of IGF-1 measurement in diagnosis [20]. A number of preexisting illnesses, including catabolic states, hepatic or renal failure, malnutrition and diabetes mellitus may lower the IGF-I level and result in false-negative values. The presence of certain key comorbid conditions (e.g., orofacial changes) can serve as an important diagnostic pointer to the presence of acromegaly, and the presence of multiple commodities (diabetes, arthralgias, cardiomyopathy, etc., summarized in Table 1) may also serve to raise suspicion to its presence. There is a clear role to be played for specialists from other disciplines (e.g., dentists), as well as primary care physicians, in the early identification of patients with acromegaly through better awareness of common comorbidities. For example, studies have shown that around $40 \%$ of patients are diagnosed by internists or family physicians, and also by ophthalmologists (if they have changes in vision), dentists (orofacial changes, separation of teeth, and malocclusion), gynecologists (menstrual irregularities and infertility), rheumatologists (joint problems), or pulmonologist (sleep apnea) [21, 22]. Many studies have provided diagnostic algorithms to help in the identification and confirmation of acromegaly [21, 23, 24], and one recent study, which has yet to be validated, has provided a scoring system to aid in the early recognition of signs and symptoms [25]. This scoring system, termed 'ACROSCORE', is intended to be used by general practitioners and nonendocrinology specialists to help in diagnosis by scoring symptoms, and depending on the final score, the patient can then be refereed for a more detailed investigation by endocrinologist. [25].

\section{Comorbidities associated with acromegaly and their management}

A better awareness and approach, and in turn control, of acromegalic comorbidities (Table 1) may help improve mortality. Due to the delayed diagnosis in many patients there are often a number of comorbidities already present at diagnosis which can act as important indicators of the 
Table 1 Clinical features of acromegaly

\begin{tabular}{ll}
\hline Mass effects of tumor & $\begin{array}{c}\text { Headache, visual impairment, hyperprolactinemia, pituitary stalk section, hypopituitarism, hypothyroidism, } \\
\text { hypogonadism, hypocortisolism }\end{array}$ \\
$\begin{array}{c}\text { Systemic effects of } \\
\text { GH/IGF-1 excess }\end{array}$ & $\begin{array}{c}\text { Soft tissue and skin changes, acral enlargement, increased skin thickness and soft tissue hypertrophy, increased } \\
\text { sweating, skin tags and acanthosis nigricans }\end{array}$ \\
Cardiovascular features & Hypertrophy, congestive heart failure, coronary disease, arrhythmias, hypertension, cardiomyopathy \\
Metabolic features & Impaired glucose metabolism, diabetes, insulin resistance \\
Respiratory features & Macroglossia, upper airway obstruction, sleep apnea, ventilator dysfunction \\
Bone and joint features & Increased articular cartilage thickness, arthropathy/osteoarthritis, carpal tunnel syndrome, vertebral fractures \\
Other endocrine & Goiter, hypercalciuria, menstrual abnormalities \\
consequences &
\end{tabular}

Adapted from Cordero and Barkan [21] and Madeira et al. [66]

disease. In one study of 324 patients, the comorbidities present at diagnosis were recorded in two groups of patients, one treated between 1981 and 1984 (early) and the other treated between 1995 and 2006 (late) [9]. The most commonly present comorbidities at diagnosis in this study were hypertension, carpal tunnel syndrome, osteoarthritis, diabetes mellitus and sleep apnea. The study also shows that presenting comorbidities have not changed between 1981 and 2006 (Table 2). While early diagnosis and therapy are obviously very important, identification and treatment of disease comorbidities should be considered as equally important [20]. Improving treatment and control, of acromegalic comorbidities has the potential to normalize mortality in acromegaly patients similar to the general public [5]. Studies have shown that with disease cure or control, it is possible to reverse some, but not all, of the associated comorbidities. Ben-Shlomo et al. summarises the outcome of different comorbidities from several studies, and shows that a number of comorbidities can improve with disease control, including joint articular cartilage thickness, vertebral fractures, left ventricular function,

Table 2 Comorbidities present at diagnosis in two groups of patients: one treated between 1981 and 1984 (early) and the other treated between 1995 and 2006 (late)

\begin{tabular}{lll}
\hline Comorbidity & Early group (\%) & Late group (\%) \\
\hline Hypertension & 37 & 36 \\
Carpal tunnel syndrome & 24 & 24 \\
Osteoarthritis & 25 & 23 \\
Diabetes mellitus & 18 & 15 \\
Sleep apnea & 13 & 29 \\
Goiter & 15 & 12 \\
Malignancy & 7.4 & 9.2 \\
Kidney stones & 8.0 & 8.0 \\
Colon polyps & 10 & 23 \\
Skin tags & 19 & 46
\end{tabular}

Adapted from Reid et al. [9] exercise capacity and endurance, lipid profile, and obstructive apnea events [5]. However, many patients never achieve disease control [5].

\section{Cardiovascular complications}

One of the most prevalent comorbidities in acromegaly patients is related to the cardiovascular system, including cardiomyopathy, atherosclerosis, and hypertension. If heart disease is present at diagnosis there is a mortality rate of $100 \%$ within 15 years [10]. In one study, the 1- and 5-yearr mortality rates for patients with heart failure were 25 and $37.5 \%$, respectively [26]. Acromegaly may be associated with a specific cardiomyopathy, characterized by left ventricular hypertrophy, arrhythmias, decreased diastolic filling, and reduced left ventricular ejection fraction [10]. It is also associated with a high prevalence of hypertension. In a meta-analysis, mean prevalence of hypertension was $35 \%$ (ranging from 18 to $60 \%$ ) in 18 series with 2562 patients [27]. Thus an early diagnosis and aggressive treatment of high blood pressure is imperative $[10,28]$. If symptoms are persistent following biochemical control of acromegaly, standard treatment with antihypertensives, including thiazide-type diuretic, calcium channel blockers angiotensin converting enzyme, or angiotensin receptor blocker $[29,30]$. There are conflicting data on the prevalence of atherosclerosis in acromegaly, with an increased incidence of carotid intima-media thickness being demonstrated by some authors, but not others [31, 32]. One study showed that the risk of coronary artery disease was low, and remained stable following successful treatment [33]. An integrated evaluation of the Framingham score and coronary artery calcium has shown that $40 \%$ of acromegalic patients were at risk for coronary atherosclerosis and that coronary calcifications were evident in about half of them [34].

Somatostatin analogues, also known as somatostatin receptor ligands (SRLs) are associated with significant 
reductions in heart rate, left ventricular mass index, interventricular septum thickness, and left ventricular posterior wall thickness. They are also associated with improved exercise tolerance, and trends toward beneficial effects for left ventricular end-diastolic dimension and ejection fraction. However, the effects were not significant for blood pressure, left ventricular, end-systolic dimension, or fractional shortening [35]. Interestingly, SRL treatment may result in improvement of cardiovascular effects regardless of biochemical control, for example, one study has shown that acromegalic cardiomyopathy was improved in patients who did not achieve biochemical control [36]. Long-term treatment with pegvisomant, on the other hand, induced a slight reduction of carotid arteries wall thickness and a significant improvement of brachial arteries vascular function in patients with acromegaly resistant to somatostatin analogues [37]. Cardiovascular function has also been reported to improve following successful transsphenoidal surgery [38], however surgery is contraindicated in patients with severe cardiomyopathy. Since cardiovascular complications, such as hypertension and heart disease negatively determine life expectancy in acromegaly, adequate control of these aspects is highly relevant to reduce the morbidity and mortality associated with this disease.

\section{Pulmonary/respiratory comorbidities}

Acromegaly patients are prone to respiratory problems, with mortality due to respiratory disease reaching $25 \%$ of cases [10]. Impaired respiratory function originates from the multiple anatomical changes associated with the disease e.g., airway anatomy, bones, muscle structure of the chest, and lung elasticity [10]. Patients with acromegaly develop barrel chest due to changes in vertebral and costal morphology, and upper airway obstruction is a result of macroglossia, prognathism, thick lips, and hypertrophy of the laryngeal mucosa and cartilage, which can result in sleep apnea and excessive snoring. Hypoventilation and hypoxemia may also develop from central respiratory depression and kyphoscoliosis [39].

Diagnosis of pulmonary complications can be carried out using a chest x-ray, spirometry, and polysomnography. Evaluations for sleep apnea in particular should be considered, with prevalence ranging from $27 \%$ in older studies to more than $80 \%$ in more recent ones [40]. Interestingly, there may be a relationship between sleep apnea and other acromegaly comorbidities, such as insulin resistance and cardiovascular problems [40-42]. Pegvisomant has been reported to cure obstructive sleep apnea in some patients and somatostatin analogues are reported to improve sleep apnea, and reduce the apnea-hypoxia index by $50 \%$ [43-45]. However, in prospective studies, sleep apnea persisted in more than $40 \%$ of patients cured of acromegaly. Therefore, patients should be reassessed after efficacious acromegaly treatment to determine whether continued sleep apnea treatment is necessary [44]. If sleep apnea persists, standard guidelines for therapy should be followed, such as noninvasive ventilation and consultation with a maxillofacial surgeons is advised and if necessary elective surgery should be undertaken [46]. Acromegaly has also been linked to increased pulmonary infections, therefore patients should be given appropriate vaccinations against influenza and pneumococcal pneumonia [29].

\section{Malignancies}

Studies on different types of cancer suggest that high 'normal levels' of IGF-I (that is, IGF-1 levels at the highest terciles) are related to an elevated cancer risk. Patients with acromegaly appear to have a higher prevalence of colon cancer [47]. There are a number of studies looking at the relationship between acromegaly and colon cancer, for which there is an increased odds ratio (2.04-4.351) [47, 48], although mortality from colon cancer does not appear to be increased [47]. In the colon, GH and IGF-1 excess leads to increased epithelial cell proliferation and decreased apoptosis rate [49]; normal and tumoral colorectal cells express large amounts of IGF-1 receptor [50, 51], and epithelial colorectal cells express the $\mathrm{GH}$ receptor [52]. Screening colonoscopy has been proposed by some groups to be carried out at diagnosis in adults, by the age of 40 or 50 by others [53] and patients should subsequently be checked as follows: (1) if colonoscopy is negative, and IGF-1 levels are normal, patients should be screened similar to the general population, (2) if colonoscopy is negative and IGF-1 levels remain elevated, more frequent screening (every 5-10 years) is recommended, and 3) if colonoscopy shows abnormalities, the follow-up should be repeated after 3-5 years [46, 54]. Repeated colonoscopic screening of patients with acromegaly has demonstrated a high prevalence of new adenomatous and hyperplastic colonic polyps, dependent on both the occurrence of previous polyps and elevated IGF-1 levels [55]. This illustrates the importance of close follow-up with these patients. Therapeutic management options for colon cancer include surgery, chemotherapy and radiotherapy, and do not differ from patients without acromegaly, however this cancer can largely be prevented by early screening and removal of adenomatous polyps [56].

In addition to colon cancer, there also appears to be a relationship between acromegaly and thyroid cancer, with reports of an increased prevalence of thyroid nodules and thyroid cancer in these patients $[57,58]$. However, because the overall rate of benign and malignant tumors appears to be similar to the general population, patients should undergo standard periodical screening for thyroid function 
and morphology [10]. Although the presence of other cancers has been observed (e.g., breast, prostate, hematologic and cervical cancers), the screening in these cases should follow the same recommendation as in the normal population [59].

\section{Orofacial changes}

Craniofacial development depends on genetic and ethnic characteristics, as well as on normal hormone secretion [60]. Normal development is characterized by the absence of asymmetries, normal maxilla-mandibular ratio, and dental contact in normal occlusion. In acromegaly there are soft tissue alterations (increased volume of tongue, uvula, lips and nose), and increased mandibular condyle-occlusion derangements [61, 62]. This can lead to functional disturbances, such as in chewing, swallowing, and speech. As the diagnosis of acromegaly is often delayed, orofacial changes such as prognathism, facial asymmetry, and dental diastemas may compromise the patients quality of life both functionally and socially. Since the dentist may be the first healthcare professional to examine the patient, they should be made aware of the disease through awareness programs. Unfortunately, unlike agromegalic changes to soft tissue, associated bone enlargement is not reversible with successful treatment. If any corrective surgical procedures are to be performed, this should only be carried out after normalization of GH and IGF-1 levels [29].

\section{Orthopedic and rheumatologic comorbidities}

Arthropathy in acromegaly is common; one Brazilian study reported as many as $56 \%$ of patients with arthropathy [63], and some studies reporting prevalence as high as $70 \%$. In many acromegaly patients, the earliest manifestations of arthropathy are articular manifestations [63-65]. Arthropathy and arthralgia may be reversible in the early stages of the disease, and adequate treatment reduces the risk of development, although it can progress even in the presence of normal levels of GH and IGF-I.

Bone disease is also highly prevalent, especially vertebral fractures with one study reporting a prevalence of around $10 \%$ in acromegaly patients [66], and another reporting more than $40 \%$ prevalence [64]. There appear to be specific risk factors for joint disease (female sex, age, obesity, duration of active acromegaly), and for arthropathy and vertebral fractures (age, hypogonadism, presence of active acromegaly) [63-65]. Early diagnosis of acromegaly can reduce the risk of joint disease and vertebral fractures, thereby improving quality of life. Adequate treatment of acromegaly reduces the risk of vertebral fractures [67], and treatment of hypogonadism improves bone mass and reduces the risk of fractures. In addition, weight loss improves joint pain in weight-bearing joints (knees and hip) [63, 64, 66]. In one study looking at the prevalence of osteoarticular changes in these patients, the authors suggest that it is important to be able to recognize and to include vertebral fracture assessments using, for example, lateral conventional radiographs of the spine in screening patients with acromegaly, both at diagnosis and during follow-up [68]. Many orthopedic/rheumatologic comorbidities persist despite biochemical control, for example, established degenerative arthritis may be irreversible, and painful arthropathy and joint complaints are a major contributor to a perceived reduced quality of life despite long-term biochemical remission [29]. Treatments for this type of persistent comorbidity should include physical therapy, anti-inflammatories and analgesic medications, with the consideration of joint replacement surgery [29]. Patients should also be assessed for osteoporosis risk factors, including vitamin $\mathrm{D}$ deficiency and inadequate calcium uptake [46].

\section{Metabolic disorders}

Acromegaly is frequently associated with metabolic problems, such as diabetes and impaired glucose tolerance. Diabetes occurs more frequently in patients with acromegaly than the general population, and is an important predictive factor for increased mortality [7, 69]. In a recent study the prevalence of diabetes mellitus and early carbohydrate metabolic disorders considerably exceeds that of the general population [69]. A further study screening of 2270 individuals in Brazil with diabetes mellitus or glucose intolerance to evaluate the frequency of acromegaly in these adults, estimated the prevalence to be 480 cases per million adults [70]. Treatment of diabetes should be the same as for patients without acromegaly. Lowering $\mathrm{GH}$ levels improves glycemic control whatever mode of treatment is used [46]. However, modifications of glucose homeostasis induced by somatostatin analogues may have an overall minor clinical impact in acromegaly despite their significant improvement of GH and IGF-1 control [71]. In patients where somatostatin worsens glucose control by inhibiting insulin secretion, alternative therapies such as pegvisomant should be considered [29]. In studies with pegvisomant, glucose levels are reduced and insulin sensitivity is improved [72]. Furthermore, successful surgical treatment of acromegaly may improve or reverse the abnormalities in the metabolism of glucose, lipids and lipoproteins [38, 73, 74]. A recently-approved SRL, pasireotide, which binds to multiple somatostatin receptors, unlike first generation SRLs, appears to have superior efficacy compared to octreotide (a first generation SRL), and a similar tolerability profile with the exception of raised hyperglycemia [75, 76]. Although this may be more 
efficacious than other treatments in the same class, and therefore an attractive choice, the increased risk of hyperglycaemia should be considered and proactively managed if chosen.

\section{Endocrine disorders}

Hormonal comorbidities are common in acromegalic patients, including hyperprolactinemia and hypopituitarism. Hyperprolactinemia develops in approximately $30 \%$ of patients due to pituitary stalk compression or mixed tumor secretion of GH and PRL, and can occur with or without galactorrhea [24]. Hypopituitarism is usually considered to be due to compression and destruction of the normal pituitary gland and/or stalk by the expanding mass; particularly a macroadenoma, and occurs in approximately $40 \%$ of patients [24]. It can also result from radiotherapy used to treat acromegaly, even after many years after the therapeutic procedure, requiring lifelong monitoring of pituitary function in these patients [77]. Patients who receive radiotherapy need lifelong monitoring of pituitary function as new deficits can occur up to 15 years or more after irradiation. Hypopituitarism may also be increased after surgical treatment for acromegaly [78], which can in turn influence cardiovascular risk [79], which is already increased in acromegalic patients.

\section{Neurologic disorders}

Some studies have reported increased neurological conditions in acromegalic patients, including intracranial aneurysm, herniation of cerebellar tonsils, hearing loss, visual impairment, headache, and carpal tunnel syndrome. This may be a result of the growing pituitary adenoma and brain volume affecting local structures. One recent study found that $17 \%$ of patients with acromegaly also had intracranial aneurisms, and that the presence of aneurisms correlated with initial serum values of $\mathrm{GH}$ [80]. The authors suggested that a neuroradiological evaluation of the intracranial circulation be done in acromegalic patients. In another study, the same group also found an increased prevalence of herniated cerebellar tonsils in these patients (15\%) compared to controls (7\%), and increased headache and visual problems [81]. The authors suggested that resolution of excess $\mathrm{GH}$ could improve on these findings. Hearing loss is also quite common in patients with acromegaly, with a prevalence ranging from 35 to $43 \%$ [8284], however the literature suggests there may be no improvement of hearing loss with hormone control [82].

Another common neurologic disorder that is commonly associated with acromegaly is carpal tunnel syndrome, and has varying reports of prevalence ranging from 18 to $84 \%$ [85, 86]; it seems that this complication could be improved with GH normalization. However, if symptoms persist after biochemical control, patients may require surgical release [29]. Lastly, the prevalence of headache in acromegaly is reported in 37 to $87 \%$ of patients, and can be a significant contributor to reduced quality of life [87]. The pathophysiology of pituitary tumor-associated headaches is not fully understood, and the resolution of headache after surgery or GH control is not always achieved [88]. However, large-scale placebo-controlled trials have shown that short-acting octreotide can reduce headache in 75-80\% of patients with acromegaly [89], and the use of slow-release monthly octreotide has been shown to reduce this symptom after the sixth injection [90]. Prospective trials of lanreotide therapy have also shown a significant reduction in headache in addition to the other symptoms of acromegaly [91]. Some of these treatments, however, can have a deleterious effect on patients, for example dependency, and possibly rebound headaches [92].

\section{Psychiatric disorders}

Patients with acromegaly often have an impaired quality of life due to the multiple comorbidities associated with the disease [12], and it is recommended that a quality of life questionnaire be used routinely during diagnosis, treatment, and monitoring of the disease [93]. These patients are also reported to have associated psychiatric disorders, which contribute to their quality of life, such as increased anxiety and decreased self-esteem [94], depression [14], and cognitive impairment [93, 95]. Many of these disorders are thought to occur more frequently in acromegaly than other somatic disorders [96]. There are a number of other psychiatric disorders associated with the different stages of the disease (Summarized in Table 3). This warrants an interdisciplinary approach, which includes psychological evaluation and assistance, in the management of the disease.

Studies have shown that both surgery and medical treatment of acromegaly can have a positive effect on physiological parameters [97], however in one study of patients with acromegaly who had biochemical remission, there was a higher prevalence of psychopathologic conditions and maladaptive personality traits compared with matched control subjects and patients with clinically nonfunctioning pituitary adenomas. These data raise the possibility of an irreversible effect of previous $\mathrm{GH}$ hypersecretion on mood and behavior [29]. 
Table 3 Symptoms in patients suffering from acromegaly before, during, and after diagnosis and treatment

\begin{tabular}{lll}
\hline Before diagnosis & After diagnosis/before surgery & After surgery \\
\hline Increased irritability & Relief & PTSD $^{\text {a }}$ \\
Increased anxiety & Impatience & Sadness \\
Emotional liability & Psychological strain & Anger \\
Feeling uncertain & Guilt & Fatigue \\
Sadness & Social withdrawal & Sleep disorders \\
Sleep disorders & Body image distortion & Body image distortion \\
Difficulty concentrating & Fear (death, surgery, family welfare) & Competence disorders \\
High stress levels & Anger & Social withdrawal \\
Lower self-esteem & Helplessness & Limited interest in daily activities \\
Loss of control & Sadness & Impaired short-term memory \\
Sense of competence loss & Sleep disorders & Denial \\
& Restlessness & Avoidance of medical staff \\
\hline
\end{tabular}

Adapted from Furman and Ezzat [98] and Szczesniak et al. [14]

a Post-traumatic stress disorder

\section{Conclusions}

New opportunities exist for early identification and monitoring of acromegaly comorbidities, and efforts should be made towards continuous awareness of this disease among primary care physicians (including those in training), specialists, dentists, and other health professionals. The presence of comorbid conditions contributes significantly to patient morbidity/mortality and impaired quality of life, and appropriate management of these comorbid conditions has the potential to improve long-term outcomes. Hormonal control of acromegaly (e.g., with surgery and/or somatostatin analogues) may contribute to the management of some comorbid conditions. However, specific therapies/ treatments may be also be required to control comorbid conditions (e.g., antihyperglycemic drugs, antihypertensives, various surgical interventions, psychological therapy). Thus, better awareness and a more aggressive approach to treat acromegaly comorbidities may contribute to improving quality of life and decreasing disease mortality.

Acknowledgments The Latin American Knowledge Network Initiative, including meetings and preparation of this supplement, was organized and funded by Ipsen. Medical writing support was provided by Dr. Catriona Paul on behalf of Arsenal-CDM Paris and funded by Ipsen. The authors were fully responsible for the concept and all content, were involved at all stages of manuscript development, and provided approval of the final version for submission.

Open Access This article is distributed under the terms of the Creative Commons Attribution 4.0 International License (http://crea tivecommons.org/licenses/by/4.0/), which permits unrestricted use, distribution, and reproduction in any medium, provided you give appropriate credit to the original author(s) and the source, provide a link to the Creative Commons license, and indicate if changes were made.

\section{References}

1. Adelman DT, Liebert KJ, Nachtigall LB, Lamerson M, Bakker B (2013) Acromegaly: the disease, its impact on patients, and managing the burden of long-term treatment. Int J Gen Med 6:31-38

2. Melmed S (2009) Acromegaly pathogenesis and treatment. J Clin Investig 119(11):3189-3202

3. Schneider HJ, Sievers C, Saller B, Wittchen HU, Stalla GK (2008) High prevalence of biochemical acromegaly in primary care patients with elevated IGF-1 levels. Clin Endocrinol (Oxf) 69(3):432-435

4. Fernandez A, Karavitaki N, Wass JA (2010) Prevalence of pituitary adenomas: a community-based, cross-sectional study in Banbury (Oxfordshire, UK). Clin Endocrinol (Oxf) 72(3):377-382

5. Ben-Shlomo A, Sheppard MC, Stephens JM, Pulgar S, Melmed S (2011) Clinical, quality of life, and economic value of acromegaly disease control. Pituitary 14(3):284-294

6. Chanson P, Salenave S (2008) Acromegaly. Orphanet J Rare Dis 3:17

7. Rajasoorya C, Holdaway IM, Wrightson P, Scott DJ, Ibbertson HK (1994) Determinants of clinical outcome and survival in acromegaly. Clin Endocrinol (Oxf) 41(1):95-102

8. Nachtigall L, Delgado A, Swearingen B, Lee H, Zerikly R, Klibanski A (2008) Changing patterns in diagnosis and therapy of acromegaly over two decades. J Clin Endocrinol Metab 93(6):2035-2041

9. Reid TJ, Post KD, Bruce JN, Nabi Kanibir M, Reyes-Vidal CM, Freda PU (2010) Features at diagnosis of 324 patients with acromegaly did not change from 1981 to 2006: acromegaly remains under-recognized and under-diagnosed. Clin Endocrinol (Oxf) 72(2):203-208

10. Colao A, Ferone D, Marzullo P, Lombardi G (2004) Systemic complications of acromegaly: epidemiology, pathogenesis, and management. Endocr Rev 25(1):102-152

11. Holdaway IM, Rajasoorya RC, Gamble GD (2004) Factors influencing mortality in acromegaly. J Clin Endocrinol Metab 89(2):667-674

12. Webb SM (2006) Quality of life in acromegaly. Neuroendocrinology 83(3-4):224-229

13. Siegel S, Streetz-van der Werf C, Schott JS, Nolte K, Karges W, Kreitschmann-Andermahr I (2013) Diagnostic delay is associated 
with psychosocial impairment in acromegaly. Pituitary 16(4): 507-514

14. Szczesniak D, Jawiarczyk-Przybylowska A, Rymaszewska J (2015) The quality of life and psychological, social and cognitive functioning of patients with acromegaly. Adv Clin Exp Med 24(1):167-172

15. Clemmons DR (2011) Clinical laboratory indices in the treatment of acromegaly. Clin Chim Acta 412(5-6):403-409

16. Clemmons DR (2011) Consensus statement on the standardization and evaluation of growth hormone and insulin-like growth factor assays. Clin Chem 57(4):555-559

17. Freda PU, Beckers AM, Katznelson L, Molitch ME, Montori VM, Post KD, Vance ML, Endocrine S (2011) Pituitary incidentaloma: an endocrine society clinical practice guideline. J Clin Endocrinol Metab 96(4):894-904

18. Schneider HJ, Kosilek RP, Gunther M, Roemmler J, Stalla GK, Sievers C, Reincke M, Schopohl J, Wurtz RP (2011) A novel approach to the detection of acromegaly: accuracy of diagnosis by automatic face classification. J Clin Endocrinol Metab 96(7):2074-2080

19. Sabino SM, Miranda PA, Ribeiro-Oliveira A Jr (2010) Growth hormone-secreting pituitary adenomas: from molecular basis to treatment options in acromegaly. Cancer Biol Ther 9(7):483-492

20. Ribeiro-Oliveira A Jr, Barkan A (2012) The changing face of acromegaly-advances in diagnosis and treatment. Nat Rev Endocrinol 8(10):605-611

21. Cordero RA, Barkan AL (2008) Current diagnosis of acromegaly. Rev Endocr Metab Disord 9(1):13-19

22. Drange MR, Fram NR, Herman-Bonert V, Melmed S (2000) Pituitary tumor registry: a novel clinical resource. J Clin Endocrinol Metab 85(1):168-174

23. Giustina A, Chanson P, Bronstein MD, Kilbanski A, Lamberts S, Casanueva FF, Trainer P, Ghigo E, Ho K, Melmed S, Acromegaly Consensus Group (2010) A consensus on criteria for cure of acromegaly. J Clin Endocrinol Metab 95(7):3141-3148

24. Lugo G, Pena L, Cordido F (2012) Clinical manifestations and diagnosis of acromegaly. Int J Endocrinol 2012:540398

25. Prencipe N, Floriani I, Guaraldi F, Di Giacomo SV, Cannavo S, Arnaldi G, Berton A, Torri V, Spinello M, Arvat E, Ghigo E, Grottoli S (2016) ACROSCORE: a new and simple tool for the diagnosis of acromegaly, a rare and underdiagnosed disease. Clin Endocrinol 84(3):380-385

26. Bihan H, Espinosa C, Valdes-Socin H, Salenave S, Young J, Levasseur S, Assayag P, Beckers A, Chanson P (2004) Long-term outcome of patients with acromegaly and congestive heart failure. J Clin Endocrinol Metab 89(11):5308-5313

27. Bondanelli M, Ambrosio MR, degli Uberti EC (2001) Pathogenesis and prevalence of hypertension in acromegaly. Pituitary 4(4):239-249

28. Vitale G, Pivonello R, Auriemma RS, Guerra E, Milone F, Savastano S, Lombardi G, Colao A (2005) Hypertension in acromegaly and in the normal population: prevalence and determinants. Clin Endocrinol (Oxf) 63(4):470-476

29. Katznelson L, Atkinson JL, Cook DM, Ezzat SZ, Hamrahian AH, Miller KK (2011) American association of clinical endocrinologists medical guidelines for clinical practice for the diagnosis and treatment of acromegaly-2011 update. Endocr Pract 17(Suppl 4): $1-44$

30. James PA, Oparil S, Carter BL, Cushman WC, Dennison-Himmelfarb C, Handler J, Lackland DT, LeFevre ML, MacKenzie TD, Ogedegbe O, Smith SC Jr, Svetkey LP, Taler SJ, Townsend RR, Wright JT Jr, Narva AS, Ortiz E (2014) 2014 evidencebased guideline for the management of high blood pressure in adults: report from the panel members appointed to the Eighth Joint National Committee (JNC 8).

JAMA 311(5):507-520
31. Colao A, Spiezia S, Cerbone G, Pivonello R, Marzullo P, Ferone D, Di Somma C, Assanti AP, Lombardi G (2001) Increased arterial intima-media thickness by B-M mode echodoppler ultrasonography in acromegaly. Clin Endocrinol (Oxf) 54(4): 515-524

32. Paisley AN, Banerjee M, Rezai M, Schofield RE, Balakrishnannair S, Herbert A, Lawrance JA, Trainer PJ, Cruickshank JK (2011) Changes in arterial stiffness but not carotid intimal thickness in acromegaly. J Clin Endocrinol Metab 96(5):1486-1492

33. Akutsu H, Kreutzer J, Wasmeier G, Ropers D, Rost C, Mohlig M, Wallaschofski H, Buchfelder M, Schofl C (2010) Acromegaly per se does not increase the risk for coronary artery disease. Eur J Endocrinol 162(5):879-886

34. Cannavo S, Almoto B, Cavalli G, Squadrito S, Romanello G, Vigo MT, Fiumara F, Benvenga S, Trimarchi F (2006) Acromegaly and coronary disease: an integrated evaluation of conventional coronary risk factors and coronary calcifications detected by computed tomography. J Clin Endocrinol Metab 91(10):3766-3772

35. Maison P, Tropeano AI, Macquin-Mavier I, Giustina A, Chanson $P$ (2007) Impact of somatostatin analogs on the heart in acromegaly: a metaanalysis. J Clin Endocrinol Metab 92(5): $1743-1747$

36. De Marinis L, Bianchi A, Mazziotti G, Mettimano M, Milardi D, Fusco A, Cimino V, Maira G, Pontecorvi A, Giustina A (2008) The long-term cardiovascular outcome of different GH-lowering treatments in acromegaly. Pituitary 11(1):13-20

37. De Martino MC, Auriemma RS, Brevetti G, Vitale G, Schiano V, Galdiero M, Grasso L, Lombardi G, Colao A, Pivonello R (2010) The treatment with growth hormone receptor antagonist in acromegaly: effect on vascular structure and function in patients resistant to somatostatin analogues. $\mathrm{J}$ Endocrinol Investig 33(9):663-670

38. Jaffrain-Rea ML, Minniti G, Moroni C, Esposito V, Ferretti E, Santoro A, Infusino T, Tamburrano G, Cantore G, Cassone R (2003) Impact of successful transsphenoidal surgery on cardiovascular risk factors in acromegaly. Eur $\mathrm{J}$ Endocrinol 148(2):193-201

39. Grunstein RR, Ho KY, Berthon-Jones M, Stewart D, Sullivan CE (1994) Central sleep apnea is associated with increased ventilatory response to carbon dioxide and hypersecretion of growth hormone in patients with acromegaly. Am J Respir Crit Care Med 150(2):496-502

40. van Haute FR, Taboada GF, Correa LL, Lima GA, Fontes R, Riello AP, Dominici M, Gadelha MR (2008) Prevalence of sleep apnea and metabolic abnormalities in patients with acromegaly and analysis of cephalometric parameters by magnetic resonance imaging. Eur J Endocrinol 158(4):459-465

41. Ip MS, Lam B, Ng MM, Lam WK, Tsang KW, Lam KS (2002) Obstructive sleep apnea is independently associated with insulin resistance. Am J Respir Crit Care Med 165(5):670-676

42. Stoohs RA, Facchini F, Guilleminault C (1996) Insulin resistance and sleep-disordered breathing in healthy humans. Am J Respir Crit Care Med 154(1):170-174

43. Grunstein RR, Ho KY, Sullivan CE (1991) Sleep apnea in acromegaly. Ann Intern Med 115(7):527-532

44. Attal P, Chanson P (2010) Endocrine aspects of obstructive sleep apnea. J Clin Endocrinol Metab 95(2):483-495

45. Kuhn E, Maione L, Bouchachi A, Roziere M, Salenave S, Brailly-Tabard S, Young J, Kamenicky P, Assayag P, Chanson P (2015) Long-term effects of pegvisomant on comorbidities in patients with acromegaly: a retrospective single-center study. Eur J Endocrinol 173(5):693-702

46. Melmed S, Casanueva FF, Klibanski A, Bronstein MD, Chanson P, Lamberts SW, Strasburger CJ, Wass JA, Giustina A (2013) A 
consensus on the diagnosis and treatment of acromegaly complications. Pituitary 16(3):294-302

47. Rokkas T, Pistiolas D, Sechopoulos P, Margantinis G, Koukoulis $\mathrm{G}$ (2008) Risk of colorectal neoplasm in patients with acromegaly: a meta-analysis. World J Gastroenterol 14(22):3484-3489

48. Renehan AG, O'Connell J, O'Halloran D, Shanahan F, Potten CS, O'Dwyer ST, Shalet SM (2003) Acromegaly and colorectal cancer: a comprehensive review of epidemiology, biological mechanisms, and clinical implications. Horm Metab Res 35(11-12):712-725

49. Cats A, Dullaart RP, Kleibeuker JH, Kuipers F, Sluiter WJ, Hardonk MJ, de Vries EG (1996) Increased epithelial cell proliferation in the colon of patients with acromegaly. Cancer Res 56(3):523-526

50. Garrouste FL, Remacle-Bonnet MM, Lehmann MM, Marvaldi JL, Pommier GJ (1997) Up-regulation of insulin/insulin-like growth factor-I hybrid receptors during differentiation of HT29-D4 human colonic carcinoma cells. Endocrinology 138(5):2021-2032

51. Sekharam M, Zhao H, Sun M, Fang Q, Zhang Q, Yuan Z, Dan HC, Boulware D, Cheng JQ, Coppola D (2003) Insulin-like growth factor 1 receptor enhances invasion and induces resistance to apoptosis of colon cancer cells through the Akt/Bcl$\mathrm{x}(\mathrm{L})$ pathway. Cancer Res 63(22):7708-7716

52. Lincoln DT, Kaiser HE, Raju GP, Waters MJ (2000) Growth hormone and colorectal carcinoma: localization of receptors. Vivo 14(1):41-49

53. Lois K, Bukowczan J, Perros P, Jones S, Gunn M, James RA (2014) The role of colonoscopic screening in acromegaly revisited: review of current literature and practice guidelines. Pituitary 18(4):568-574

54. Cairns SR, Scholefield JH, Steele RJ, Dunlop MG, Thomas HJ, Evans GD, Eaden JA, Rutter MD, Atkin WP, Saunders BP, Lucassen A, Jenkins P, Fairclough PD, Woodhouse CR, British Society of Gastroenterology, Association of Coloproctology for Great Britain and Ireland (2010) Guidelines for colorectal cancer screening and surveillance in moderate and high risk groups (update from 2002). Gut 59(5):666-689

55. Dworakowska D, Gueorguiev M, Kelly P, Monson JP, Besser GM, Chew SL, Akker SA, Drake WM, Fairclough PD, Grossman AB, Jenkins PJ (2010) Repeated colonoscopic screening of patients with acromegaly: 15-year experience identifies those at risk of new colonic neoplasia and allows for effective screening guidelines. Eur J Endocrinol 163(1):21-28

56. López PJT, Albero JS, Rodríguez-Montes JA (2014) Primary and secondary prevention of colorectal cancer. Clin Med Insights Gastroenterol 7:33-46

57. dos Santos MC, Nascimento GC, Nascimento AG, Carvalho VC, Lopes MH, Montenegro R, Montenegro R Jr, Vilar L, Albano MF, Alves AR, Parente CV, dos Santos Faria M (2013) Thyroid cancer in patients with acromegaly: a case-control study. Pituitary 16(1):109-114

58. Rogozinski A, Furioso A, Glikman P, Junco M, Laudi R, Reyes A, Lowenstein A (2012) Thyroid nodules in acromegaly. Arq Bras Endocrinol Metabol 56(5):300-304

59. Jenkins PJ (2006) Cancers associated with acromegaly. Neuroendocrinology 83(3-4):218-223

60. Nanda RS (2000) The contributions of craniofacial growth to clinical orthodontics. Am J Orthod Dentofacial Orthop 117(5):553-555

61. Jadresic A, Banks LM, Child DF, Diamant L, Doyle FH, Fraser TR, Joplin GF (1982) The acromegaly syndrome. Relation between clinical features, growth hormone values and radiological characteristics of the pituitary tumours. Q J Med 51(202):189-204

62. Sugata T, Myoken Y, Tanaka S (1998) Acromegaly identified in a patient with a complaint of malocclusion. Oral Surg Oral Med Oral Pathol Oral Radiol Endod 85(1):44-46
63. Kropf LL, Madeira M, Neto LV, Gadelha MR, de Farias ML (2013) Functional evaluation of the joints in acromegalic patients and associated factors. Clin Rheumatol 32(7):991-998

64. Mazziotti G, Bianchi A, Porcelli T, Mormando M, Maffezzoni F, Cristiano A, Giampietro A, De Marinis L, Giustina A (2013) Vertebral fractures in patients with acromegaly: a 3-year prospective study. J Clin Endocrinol Metab 98(8):3402-3410

65. Killinger Z, Payer J, Lazurova I, Imrich R, Homerova Z, Kuzma M, Rovensky J (2010) Arthropathy in acromegaly. Rheum Dis Clin North Am 36(4):713-720

66. Madeira M, Neto LV, Torres CH, de Mendonca LM, Gadelha MR, de Farias ML (2013) Vertebral fracture assessment in acromegaly. J Clin Densitom 16(2):238-243

67. Wassenaar MJ, Biermasz NR, Hamdy NA, Zillikens MC, van Meurs JB, Rivadeneira F, Hofman A, Uitterlinden AG, Stokkel MP, Roelfsema F, Kloppenburg M, Kroon HM, Romijn JA, Pereira AM (2011) High prevalence of vertebral fractures despite normal bone mineral density in patients with long-term controlled acromegaly. Eur J Endocrinol 164(4):475-483

68. Scarpa R, De Brasi D, Pivonello R, Marzullo P, Manguso F, Sodano A, Oriente P, Lombardi G, Colao A (2004) Acromegalic axial arthropathy: a clinical case-control study. J Clin Endocrinol Metab 89(2):598-603

69. Dreval AV, Trigolosova IV, Misnikova IV, Kovalyova YA, Tishenina RS, Barsukov IA, Vinogradova AV, Wolffenbuttel BH (2014) Prevalence of diabetes mellitus in patients with acromegaly. Endocr Connect 3(2):93-98

70. Rosario PW (2011) Frequency of acromegaly in adults with diabetes or glucose intolerance and estimated prevalence in the general population. Pituitary 14(3):217-221

71. Mazziotti G, Floriani I, Bonadonna S, Torri V, Chanson P, Giustina A (2009) Effects of somatostatin analogs on glucose homeostasis: a metaanalysis of acromegaly studies. J Clin Endocrinol Metab 94(5):1500-1508

72. Rose DR, Clemmons DR (2002) Growth hormone receptor antagonist improves insulin resistance in acromegaly. Growth Horm IGF Res 12(6):418-424

73. Oscarsson J, Wiklund O, Jakobsson KE, Petruson B, Bengtsson BA (1994) Serum lipoproteins in acromegaly before and 6-15 months after transsphenoidal adenomectomy. Clin Endocrinol (Oxf) 41(5):603-608

74. Wiesli P, Bernays R, Brandle M, Zwimpfer C, Seiler H, Zapf J, Spinas GAS, Schmid C (2005) Effect of pituitary surgery in patients with acromegaly on adiponectin serum concentrations and alanine aminotransferase activity. Clin Chim Acta 352(1-2):175-181

75. McKeage K (2015) Pasireotide in acromegaly: a review. Drugs 75(9):1039-1048

76. Sheppard M, Bronstein MD, Freda P, Serri O, De Martinis L, Naves L, Rozhinskaya L, Hermosillo Reséndiz K, Ruffin M, Chen Y, Colao A (2015) Pasireotide LAR maintains inhibition of GH and IGF-1 in patients with acromegaly for up to 25 months: results from the blinded extension phase of a randomized, doubleblind, multicenter. Phase III study. Pituitary 18(3):385-394

77. Darzy KH (2013) Radiation-induced hypopituitarism. Curr Opin Endocrinol Diabetes Obes 20(4):342-353

78. Carvalho P, Lau E, Carvalho D (2015) Surgery induced hypopituitarism in acromegalic patients: a systematic review and meta-analysis of the results. Pituitary 18(6):844-860

79. Harbeck B, Haas CS, Suefke S, Moenig H (2015) Cardiovascular risk in patients with hypothalamic-pituitary disorders. Int J Cardiol 184:464-465

80. Manara R, Maffei P, Citton V, Rizzati S, Bommarito G, Ermani M, Albano I, Della Puppa A, Carollo C, Pavesi G, Scanarini M, Ceccato F, Sicolo N, Mantero F, Scaroni C, Martini C (2011) Increased rate of intracranial saccular aneurysms in acromegaly: 
an MR angiography study and review of the literature. J Clin Endocrinol Metab 96(5):1292-1300

81. Manara R, Bommarito G, Rizzati S, Briani C, Della Puppa A, Citton V, Zanchetta E, Zerbo F, Ermani M, Martini C, Mantero F, Sicolo N, Maffei P, Scaroni C (2013) Herniation of cerebellar tonsils in acromegaly: prevalence, pathogenesis and clinical impact. Pituitary 16(1):122-130

82. Carvalho MA, Montenegro Junior RM, Freitas MR, Vilar L, Mendonca AT, Montenegro RM (2012) Sensorineural hearing loss in acromegalic patients under treatment. Braz J Otorhinolaryngol 78(4):98-102

83. Aydin K, Ozturk B, Turkyilmaz MD, Dagdelen S, Ozgen B, Unal F, Erbas T (2012) Functional and structural evaluation of hearing in acromegaly. Clin Endocrinol (Oxf) 76(3):415-419

84. Babic BB, Petakov MS, Djukic VB, Ognjanovic SI, Arsovic NA, Isailovic TV, Milovanovic JD, Macut D, Damjanovic SS (2006) Conductive hearing loss in patients with active acromegaly. Otol Neurotol 27(6):865-870

85. Mestron A, Webb SM, Astorga R, Benito P, Catala M, Gaztambide S, Gomez JM, Halperin I, Lucas-Morante T, Moreno B, Obiols G, de Pablos P, Paramo C, Pico A, Torres E, Varela C, Vazquez JA, Zamora J, Albareda M, Gilabert M (2004) Epidemiology, clinical characteristics, outcome, morbidity and mortality in acromegaly based on the Spanish Acromegaly Registry (Registro Espanol de Acromegalia, REA). Eur J Endocrinol 151(4):439-446

86. Kameyama S, Tanaka R, Hasegawa A, Tamura T, Kuroki M (1993) Subclinical carpal tunnel syndrome in acromegaly. Neurol Med Chir (Tokyo) 33(8):547-551

87. Giustina A, Gola M, Colao A, De Marinis L, Losa M, Sicolo N, Ghigo E (2008) The management of the patient with acromegaly and headache: a still open clinical challenge. J Endocrinol Investig 31(10):919-924

88. Levy MJ, Matharu M, Goadsby PJ (2008) Chronic headache and pituitary tumors. Curr Pain Headache Rep 12(1):74-78
89. Levy MJ (2011) The association of pituitary tumors and headache. Curr Neurol Neurosci Rep 11(2):164-170

90. Lancranjan I, Atkinson AB, Sandostatin LAR Group (1999) Results of a European multicentre study with Sandostatin LAR in acromegalic patients. Pituitary 1(2):105-114

91. Cannavo S, Squadrito S, Curto L, Almoto B, Trimarchi F (2001) Effectiveness of slow-release lanreotide in previously operated and untreated patients with $\mathrm{GH}$-secreting pituitary macroadenoma. Horm Metab Res 33(10):618-624

92. May A, Lederbogen S, Diener HC (1994) Octreotide dependency and headache: a case report. Cephalalgia 14(4):303-304

93. Pereira AM, Tiemensma J, Romijn JA, Biermasz NR (2012) Cognitive impairment and psychopathology in patients with pituitary diseases. Neth J Med 70(6):255-260

94. Pantanetti P, Sonino N, Arnaldi G, Boscaro M (2002) Self image and quality of life in acromegaly. Pituitary 5(1):17-19

95. Leon-Carrion J, Martin-Rodriguez JF, Madrazo-Atutxa A, SotoMoreno A, Venegas-Moreno E, Torres-Vela E, Benito-Lopez P, Galvez MA, Tinahones FJ, Leal-Cerro A (2010) Evidence of cognitive and neurophysiological impairment in patients with untreated naive acromegaly. J Clin Endocrinol Metab 95(9):4367-4379

96. Sievers C, Dimopoulou C, Pfister H, Lieb R, Steffin B, Roemmler J, Schopohl J, Mueller M, Schneider HJ, Ising M, Wittchen HU, Stalla GK (2009) Prevalence of mental disorders in acromegaly: a cross-sectional study in 81 acromegalic patients. Clin Endocrinol (Oxf) 71(5):691-701

97. Matta MP, Couture E, Cazals L, Vezzosi D, Bennet A, Caron P (2008) Impaired quality of life of patients with acromegaly: control of GH/IGF-1 excess improves psychological subscale appearance. Eur J Endocrinol 158(3):305-310

98. Furman K, Ezzat S (1998) Psychological features of acromegaly. Psychother Psychosom 67(3):147-153 